\title{
Analysis of tumor necrosis factor $\alpha$-induced and nuclear factor $\kappa B$-silenced LNCaP prostate cancer cells by RT-qPCR
}

\author{
CEREN GONEN-KORKMAZ, GULNUR SEVIN, GOKSEL GOKCE, MEHMET ZUHURI ARUN, \\ GOKCE YILDIRIM, BUKET REEL, AYSEGUL KAYMAK and DENIZ OGUT \\ Department of Pharmacology, Faculty of Pharmacy, Ege University, Izmir 35100, Turkey
}

Received January 20, 2014; Accepted October 6, 2014

DOI: $10.3892 /$ etm.2014.2032

\begin{abstract}
Prostate cancer is the second leading cause of morbidity and mortality in males in the Western world. In the present study, LNCaP, which is an androgen receptor-positive and androgen-responsive prostate cancer cell line derived from lymph node metastasis, and DU145, which is an androgen receptor-negative prostate cancer cell line derived from brain metastasis, were investigated. TNF $\alpha$ treatment decreased p105 and p50 expression and R1881 treatment slightly decreased p105 expression but increased p50 expression with or without $\mathrm{TNF} \alpha$ induction. As an aggressive prostate cancer cell line, DU145 transfected with six transmembrane protein of prostate (STAMP)1 or STAMP2 was also exposed to TNFa. Western blotting indicated that transfection with either STAMP gene caused a significant increase in $\mathrm{NF \kappa B}$ expression following $\mathrm{TNF} \alpha$ induction. In addition, following the treatment of LNCaP cells with $\mathrm{TNF} \alpha$, reverse transcription quantitative polymerase chain reaction (RT-qPCR) was performed with a panel of apoptosis-related gene primers. The apoptosis-related genes p53, p73, caspase 7 and caspase 9 showed statistically significant increases in expression levels while the expression levels of MDM2 and STAMP1 decreased following TNF $\alpha$ induction. Furthermore, LNCaP cells were transfected with a small interfering $\mathrm{NF \kappa B}$ (siNFkB) construct for 1 and 4 days and induced with TNFa for the final $24 \mathrm{~h}$. RT-qPCR amplifications were performed with apoptosis-related gene primers,
\end{abstract}

Correspondence to: Dr Ceren Gonen-Korkmaz, Department of Pharmacology, Faculty of Pharmacy, Ege University, Bornova, Izmir 35100, Turkey

E-mail: korkmaz_ceren@yahoo.com

Abbreviations: MDM2, E3 ubiquitin ligase; TNF, tumor necrosis factor; $\mathrm{NF \kappa B}$, nuclear factor $\kappa \mathrm{B}$; STEAP, six transmembrane epithelial antigen of prostate; STAMP, six transmembrane protein of prostate

Key words: prostate cancer, cell culture, gene silencing, NFкB, $\mathrm{TNF} \alpha, \mathrm{p} 53$, STAMP genes including p53, caspases and STAMPs. However, no changes in the level of STAMP2 were observed between cells in the presence or absence of TNF $\alpha$ induction or between those transfected or not transfected with siNFkB; however, the level of STAMP1 was significantly decreased by TNFa induction, and significantly increased with siNF $\mathrm{B}$ transfection. Silencing of the survival gene $\mathrm{NF \kappa B}$ caused anti-apoptotic STAMP1 expression to increase, which repressed p53, together with MDM2. NFkB silencing had varying effects on a panel of cancer regulatory genes. Therefore, the effective inhibition of NFKB may be critical in providing a targeted pathway for prostate cancer prevention.

\section{Introduction}

Prostate cancer is the most commonly diagnosed cancer and the second leading cause of cancer mortality in males in the Western world. Human prostate adenocarcinoma cell lines are normally resistant to programmed cell death, known as apoptosis (1).

Six transmembrane epithelial antigen of the prostate (STEAP) (2) belongs to the six transmembrane protein of prostate (STAMP) gene family, and is the first characterized transmembrane gene that is enriched in the prostate. STEAP is expressed in metastatic prostate cancer samples; in particular, STAMP1/STEAP2 (3) and STAMP2/STEAP4 (4) are expressed in the androgen receptor-positive prostate cancer cell line $\mathrm{LNCaP}$, and androgen receptor-mediated regulation of STAMP2 has previously been demonstrated (4). The role of STAMP2 in metabolic disease and its function in the prevention of excessive inflammation and protection of adipocyte insulin sensitivity and systemic glucose homeostasis has been reported in mice (5). Other members of the STAMP family include pHyde, a rat protein that has been implicated in the apoptosis of prostate cancer cells (6), and its human homolog, tumor suppressor-activated pathway 6 (TSAP6), also known as STEAP3, a p53-inducible gene, involved in apoptosis and the cell cycle in prostate cancer and HeLa cells (7).

It is hypothesized that STAMP/STEAP family genes may have similar functions, with roles in the normal biology and pathophysiology of prostate cancer. Activation of extracellular signal-regulated kinase (ERK), which has previously 
been implicated in prostate cancer progression, was reported with ectopic expression of STAMP1 in DU145 cells and, conversely, was strongly downregulated in LNCaP cells following STAMP1 knockdown (8). The promoter regions of STAMP genes have been analyzed, and tumor suppressor gene p53 response elements and nuclear factor $\kappa \mathrm{B}(\mathrm{NF \kappa B})$ response elements identified and confirmed in the promoter region of STAMP genes (Gonen-Korkmaz et al, unpublished data). In the present study, tumor necrosis factor $\alpha(\mathrm{TNF} \alpha)$-induced apoptosis in the LNCaP (human prostate adenocarcinoma lymph node metastasis) cell line was investigated by amplifications conducted using a panel of apoptosis-related gene primers. The LNCaP cell line expresses STAMP1 and STAMP2. Another prostate cancer cell line, DU145, which is derived from brain metastasis, was transfected with STAMP1 and STAMP2 and then induced by TNF $\alpha$. The apoptosis/survival equilibrium, which is determined by $\mathrm{NF \kappa B}$, was investigated by western blot analysis of the two cell lines.

\section{Materials and methods}

Cell culture. LNCaP cells were cultured in RPMI-1640 (Gibco-BRL, Gaithersburg, MD, USA) with $10 \%$ fetal bovine serum (FBS), while DU145 cells were cultured in Dulbecco's modified Eagle's medium (DMEM)-Ham's F12 (Gibco-BRL) with 5\% FBS, $1 \%$ L-glutamine and $1 \mathrm{U} / \mathrm{ml}$ each of penicillin/streptomycin. Cells were incubated at $37^{\circ} \mathrm{C}$ with $5 \% \mathrm{CO}_{2}$ in a humidified atmosphere. The cell lines were purchased from ATCC (Manassas, VA, USA).

Primer design, plasmid construction and transfection. The full-length open reading frames of STAMP1 and STAMP2 were amplified using primers (10 pmol of each), designed using Light Cycler Probe Design Software 2 (Roche Diagnostics, Mannheim, Germany). The PCR product was cloned into pcDNA4-HisMax-TOPO (Invitrogen Life Technologies, Carlsbad, CA, USA) vector, in accordance with the manufacturer's instructions. The inserts were verified by PCR amplifications. All transfections including small interfering RNA (siRNA) were performed using FuGENE HD (Roche Diagnostics) transfection reagent, in accordance with the manufacturer's instructions. Briefly, cells were seeded in 6-well plates one day prior to transfection. The following day, the transfection solution was prepared in a 1.5-ml tube with $100 \mu 1$ pre-warmed RPMI-1640 (without antibiotics), $1 \mu \mathrm{g}$ pcDNA4-HisMax-gene plasmid DNA was added and the solution was incubated for $5 \mathrm{~min}$. A total of $3 \mu \mathrm{l}$ FuGENE HD transfection reagent was added dropwise with tapping to mix, and, following a 15-min incubation at room temperature, the transfection mix was added to the cells dropwise.

siRNA-mediated knockdown of NFKB. LNCaP cells were transfected with either scrambled control siRNA (sc-37007) or NFkB-specific siRNA (sc-29410), purchased from Santa Cruz Biotechnology Inc. (Dallas, TX, USA). The sequences were provided by the manufacturer.

A total of 100 pmol siRNA (final concentration, $50 \mathrm{nM}$ ) was used to transfect cells with the aid of $10 \mu 1$ FuGENE HD transfection reagent and the cells were incubated with the
siRNA construct for 1 and 4 days, respectively, in accordance with the manufacturer's instructions.

Treatment of the cells. The LNCaP cells were divided into four groups. The control group was cultured in the absence of treatment for $24 \mathrm{~h}$; the TNFa induction group was induced by TNFa (100 ng/ml; Sigma, St. Louis, MO, USA) for $24 \mathrm{~h}$. the R1881 group was treated for $24 \mathrm{~h}$ with a synthetic androgen, R1881 (1x10-8 M; Sigma); and the TNF + R1881 group was treated concomitantly with $\mathrm{TNF} \alpha(100 \mathrm{ng} / \mathrm{ml})$ and $\mathrm{R} 1881$ $\left(1 \times 10^{-8} \mathrm{M}\right)$ for $24 \mathrm{~h}$.

DU145 cells transfected with STAMP1 or STAMP2 were induced by TNFa $(100 \mathrm{ng} / \mathrm{ml})$ or were not induced for $24 \mathrm{~h}$.

In another series of experiments, following $\mathrm{NF} \kappa \mathrm{B}$ gene silencing, the LNCaP cells transfected for 1 day were induced by TNF $\alpha(100 \mathrm{ng} / \mathrm{ml})$ or were not induced for a further $24 \mathrm{~h}$. The cells transfected for 4 days were induced by TNF $\alpha(100 \mathrm{ng} / \mathrm{ml})$ or were not induced at the third day of transfection.

Reverse transcription quantitative polymerase chain reaction (RT-qPCR) using a panel of apoptosis-related gene primers. qPCR was performed using a Light Cycler $^{\circledR} 480$ (Roche Diagnostics) instrument and Light Cycler 480 SYBR Green 1 Master kit (Roche Diagnostics). Briefly, the reactions were performed in a $20-\mu 1$ volume with 5 pmol of each primer and $1 \mu l$ of cDNA template derived from reverse-transcribed RNA of scrambled siRNA (control) and NFkB siRNA-transfected cells. The primers used are shown in Table I. GAPDH, a human housekeeping gene, was used as an endogenous control and reference gene for relative quantifications. The same thermal profile was optimized for all primers: pre-incubation for $5 \mathrm{~min}$ at $95^{\circ} \mathrm{C}$ for 1 cycle, followed by 40 cycles of denaturation at $95^{\circ} \mathrm{C}$ for $10 \mathrm{sec}$, primer annealing at $64^{\circ} \mathrm{C}$ for $20 \mathrm{sec}$, and primer extension at $72^{\circ} \mathrm{C}$ for $10 \mathrm{sec}$. Water was included as a no-template control. Melting curves were derived after 40 cycles by a denaturation step at $95^{\circ} \mathrm{C}$ for $10 \mathrm{sec}$, followed by annealing at $65^{\circ} \mathrm{C}$ for $15 \mathrm{sec}$, and a temperature rise to $95^{\circ} \mathrm{C}$ with a heating rate of $0.1^{\circ} \mathrm{C} / \mathrm{sec}$ and continuous fluorescence measurement. Final cooling was performed at $37^{\circ} \mathrm{C}$ for $30 \mathrm{sec}$. Melting curve analyses of each sample were performed using LightCycler 480 Software version LCS480 (Roche Diagnostics). The analysis step of relative quantification was a fully automated process accomplished by the software, with the efficiency set at 2 and the cDNA of untreated cells defined as the calibrator.

Cell lysis, protein extraction and western blot analysis. For protein extraction, cells were grown on 60-mm culture dishes (Orange Scientific, Braine-l'Alleud, Belgium) and washed once with phosphate-buffered saline (PBS) prior to cell lysis. Cells were resuspended in $250 \mu \mathrm{l}$ modified radioimmunoprecipitation assay (RIPA) lysis buffer (10 mM Tris Cl, pH 8.0; $1 \%$ Triton $\mathrm{X}-100 ; 0.1 \%$ SDS; $0.1 \%$ Na deoxycholate; 1 mM EDTA; $1 \mathrm{mM}$ EGTA; $140 \mathrm{mM} \mathrm{NaCl}$ ) containing protease and phosphatase inhibitors. Cells were collected from culture plates using a cell scraper and were transferred to Eppendorf tubes. Cells were incubated on ice for $1 \mathrm{~h}$ (with pipetting up/down every $10 \mathrm{~min}$ ), centrifuged at $14,000 \mathrm{x} \mathrm{g}$ for $30 \mathrm{~min}$ and the cleared supernatants were then collected. The protein concentration was determined using the Qubit Protein assay kit (Invitrogen 
Table I. Genes and primers used as an apoptosis panel for quantitative polymerase chain reaction (qPCR) analysis.

GenBank/

Symbol

Description

Gene name

Primer sequence

\begin{tabular}{|c|c|c|c|}
\hline $\begin{array}{l}\text { NM_005163/ } \\
\text { AKT1 }\end{array}$ & $\begin{array}{l}\text { V-akt murine thymoma } \\
\text { viral oncogene homolog } 1\end{array}$ & PKB/PRKBA & $\begin{array}{l}\text { Forward: TCCCCCTCAGATGATCTCTCCA } \\
\text { Reverse: CGGAAAGGTTAAGCGTCGAAAA }\end{array}$ \\
\hline $\begin{array}{l}\text { NM_001227/ } \\
\text { CASP7 }\end{array}$ & $\begin{array}{l}\text { Caspase } 7 \text {, apoptosis- } \\
\text { related cysteine peptidase }\end{array}$ & CMH-1/ICE-LAP3 & $\begin{array}{l}\text { Forward:AAGTGAGGAAGAGTTTATGGCAA } \\
\text { Reverse: CCATCTTGAAAACAAAGTGCCAA }\end{array}$ \\
\hline $\begin{array}{l}\text { NM_001229/ } \\
\text { CASP9 }\end{array}$ & $\begin{array}{l}\text { Caspase } 9 \text {, apoptosis- } \\
\text { related cysteine peptidase }\end{array}$ & APAF-3/APAF3 & $\begin{array}{l}\text { Forward: TCCTGAGTGGTGCCAAACAAAA } \\
\text { Reverse: AGTGGTTGTCAGGCGAGGAAAG }\end{array}$ \\
\hline $\begin{array}{l}\text { NM_005427/ } \\
\text { TP73 }\end{array}$ & Tumor protein $\mathrm{p} 73$ & P73 & $\begin{array}{l}\text { Forward: AGCAGCCCATCAAGGAGGAGTT } \\
\text { Reverse: TCCTGAGGCAGTTTTGGACACA }\end{array}$ \\
\hline $\begin{array}{l}\text { NM_000546/ } \\
\text { TP53 }\end{array}$ & $\begin{array}{l}\text { Tumor protein } \mathrm{p} 53 \\
\text { (Li-Fraumeni syndrome) }\end{array}$ & CYS51STOP/P53 & $\begin{array}{l}\text { Forward: AGATGGGGTCTCACAGTGTTGC } \\
\text { Reverse: ATGTTGACCCTTCCAGCTCCAC }\end{array}$ \\
\hline $\begin{array}{l}\text { NM_002392/ } \\
\text { MDM2 }\end{array}$ & $\begin{array}{l}\text { MDM2 proto-oncogene, } \\
\text { E3 ubiquitin ligase }\end{array}$ & HDMX/MGC71221 & $\begin{array}{l}\text { Forward: GGGTTCGCACCATTCTCCTG } \\
\text { Reverse: GGCAGATGACTGTAGGCCAAGC }\end{array}$ \\
\hline $\begin{array}{l}\text { NM_152999.3/ } \\
\text { STAMP1 }\end{array}$ & $\begin{array}{l}\text { STEAP family member } 2 \text {, } \\
\text { metalloreductase (STEAP2), } \\
\text { transcript variant } 1\end{array}$ & STEAP2/STAMP1 & $\begin{array}{l}\text { Forward: ATAGGAAGTGGGGATTTTGC } \\
\text { Reverse: AGATGTCTCAGGTCCCACAA }\end{array}$ \\
\hline $\begin{array}{l}\text { NM_024636.3/ } \\
\text { STAMP2 }\end{array}$ & $\begin{array}{l}\text { STEAP family member } 4 \\
\text { (STEAP4), transcript } \\
\text { variant } 1\end{array}$ & STEAP4/STAMP2 & $\begin{array}{l}\text { Forward: GCACTTACACTGCTTGC } \\
\text { Reverse: CAGTGGTCAAGCCAGTC }\end{array}$ \\
\hline $\begin{array}{l}\text { NM_002046/ } \\
\text { GAPDH }\end{array}$ & $\begin{array}{l}\text { Glyceraldehyde-3-phosphate } \\
\text { dehydrogenase }\end{array}$ & G3PD, GAPD & $\begin{array}{l}\text { Forward: CATTGCCCTCAACGACCACTTT } \\
\text { Reverse: GGTGGTCCAGGGGTCTTACTCC }\end{array}$ \\
\hline
\end{tabular}

GenBank accession numbers for reference mRNA sequences, gene names and and descriptions are as provided by the RefSeq database of the National Center for Biotechnology Information.

Life Technologies) where appropriate. SDS-PAGE and western blot analysis was performed under standard conditions using $20 \mu \mathrm{g}$ lysate per lane. Proteins were separated on a $10 \%$ gel and transferred to a polyvinylidene difluoride (PVDF) membrane (Amersham Pharmacia Biotech, Amersham, UK) using a semi-dry transfer blotter (VWR International Ltd., Lutterworth, UK). The PVDF membrane was blocked with $10 \%$ dry milk in PBS solution containing $0.1 \%$ Tween 20 (PBS-T) for $10 \mathrm{~min}$. Primary and secondary antibody incubations were performed using PBS-T containing $0.5 \%$ dry milk at $4^{\circ} \mathrm{C}$ overnight. Membranes were developed using enhanced chemiluminescence (ECL) plus reagent (Amersham Pharmacia Biotech) for $5 \mathrm{~min}$, and images were captured using a FX7 dark room chemiluminescence camera (Vilber Lourmat, Marne-laVallée, France). The antibodies used were mouse anti-human NFKB (p50/p105) monoclonal antibody (sc-166588; Santa Cruz Biotechnology) used at a dilution of 1:1,000 and mouse anti-human $\beta$-actin monoclonal antibody (A5316; Sigma) used at a dilution of 1:20,000. The secondary antibody was mouse anti-rabbit IgG-HRP polyclonal antibody (sc-2357; Santa Cruz Biotechnology) used at a dilution of 1:10,000.

Statistical analysis. All results represent one of at least three independent experiments with similar outcomes. All data are expressed as the mean \pm standard error of mean. One-way analysis of variance (ANOVA) and Tukey post hoc test were used to compare groups of data. $\mathrm{P} \leq 0.05$ was considered to indicate a statistically significant result. GraphPad Software, Version 4.03 (San Diego, CA, USA) was used for the statistical analysis.

\section{Results}

Effects of TNF $\alpha$ induction with or without R1881 treatment on the expression of p50 and p105 in LNCaP cells. LNCaP cells were treated with $\mathrm{TNF} \alpha$ in the presence or absence of $\mathrm{R} 1881$, which is a synthetic androgen analog. TNF $\alpha$ induction, R1881 treatment and TNF $\alpha$ induction plus R1881 treatment led to reductions in p105 expression levels. Treatment with $\mathrm{TNF} \alpha$ alone caused a slight reduction in the p50 expression level, whereas R1881 treatment increased the protein expression level of p50 in the presence or absence of TNF $\alpha$ (Fig. 1).

Effects of STAMP1 and STAMP2 transfections with or without TNF $\alpha$ induction on the expression of 50 in DU145 cells. DU145 cells were transfected with HisMax-vector, HisMax-STAMP1 or HisMax-STAMP2. The transfected cells were then either induced by TNF $\alpha$ or were not induced. HisMAX-STAMP1 transfection decreased the expression level of p50. However, TNF $\alpha$ induction following HisMAX-STAMP1 transfection led to an increase in the expression level of p50. By contrast, HisMAX-STAMP2 transfection increased the expression level of $\mathrm{p} 50$, and $\mathrm{TNF} \alpha$ induction had no effect on the expression 


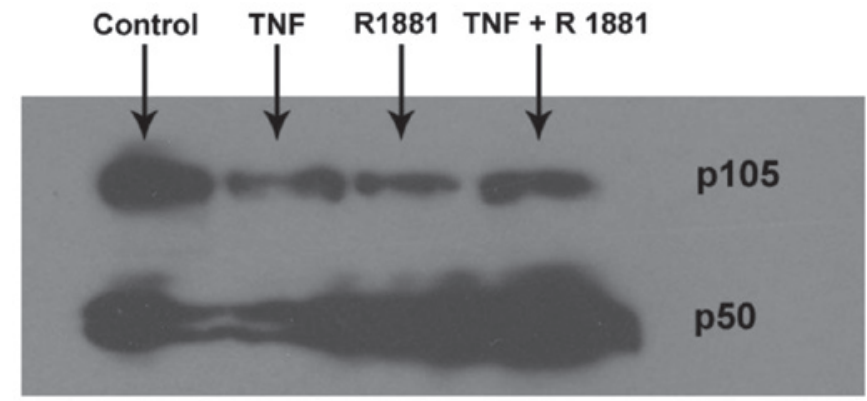

B-actin

Figure 1. Protein expression of p50 and p105 in LNCaP cells as revealed by western blotting. $\mathrm{LNCaP}$ cells were induced with $\mathrm{TNF} \alpha$ in the presence or absence of synthetic androgen R1881.
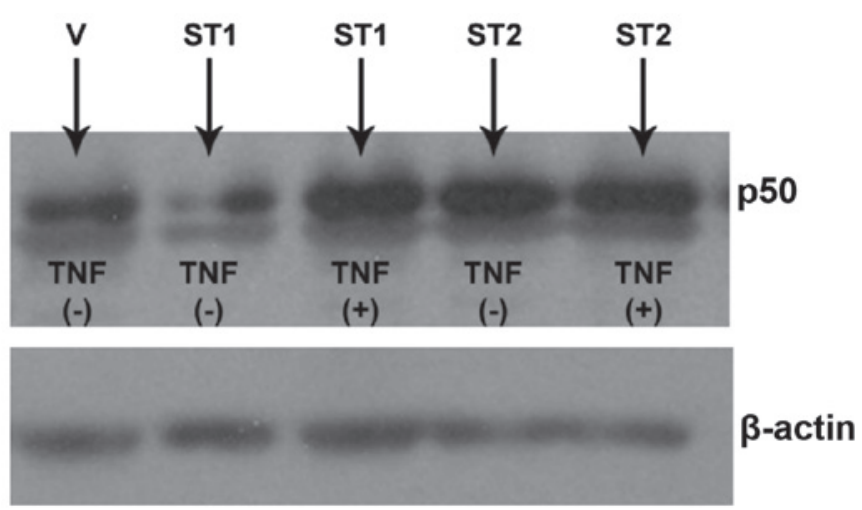

Figure 2. Protein expression of p50 in DU145 cells as revealed by western blotting. DU145 cells were transfected with HisMax-vector (V), HisMaxSTAMP1 (ST1) or HisMax-STAMP2 (ST2). Transfected cells were induced by $\mathrm{TNF} \alpha$ or not induced.

level of p50 in cells transfected with HisMAX-STAMP2 (Fig. 2).

Effects of TNF $\alpha$ induction on apoptosis-related gene expression in LNCaP cells. RT-qPCR amplifications were performed with a panel of apoptosis-related primers following the induction of LNCaP cells with TNF $\alpha$. Induction with TNF $\alpha$ led to increases in the mRNA levels of the apoptosis-related genes p53, p73, caspase 7 and caspase 9, and the survival-related gene AKT1. Conversely, TNF $\alpha$ induction tended to decrease the mRNA levels of MDM2 and STAMP1; however, the reductions were not significant. The mRNA levels of STAMP2 were unaffected by TNF $\alpha$ induction (Fig. 3).

Effect of $N F \kappa B$ gene silencing with or without TNF $\alpha$ induction on apoptosis-related gene expression in LNCaP cells. Cells were transfected with siNFKB construct or scrambled control for 1 or 4 days. The cells transfected for 1 day were induced by $\mathrm{TNF} \alpha$ or were not induced for a further $24 \mathrm{~h}$ in serum medium. The cells transfected for 4 days were induced by TNF $\alpha$ or not induced for $24 \mathrm{~h}$ at the third day of transfection.

TNF $\alpha$ induction increased the mRNA levels of p53, p73, AKT1 and caspases 7 and 9, and also tended to decrease the

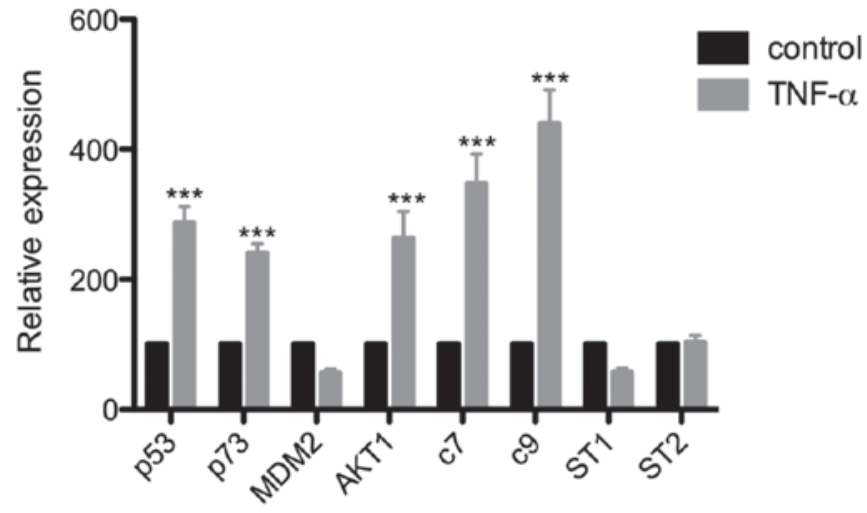

Figure 3. Effects of TNF $\alpha$ induction on the mRNA expression of apoptosisrelated genes in $\mathrm{LNCaP}$ cells. ${ }^{* * *} \mathrm{P} \leq 0.001$ vs. control, compared by one-way analysis of variance followed by Tukey post hoc test.

mRNA levels of MDM2 and STAMP1 in the LNCaP cells transfected with scrambled control (Figs. 4 and 5).

Silencing of the NFKB gene decreased the mRNA levels of p53 (Fig. 5). NFkB gene silencing also attenuated the effect of TNFa induction on the mRNA levels of p53 at day 1 (Fig. 4). Silencing of the NFKB gene inhibited the effect of TNF $\alpha$ induction on the mRNA levels of p53 at day 4 (Fig 5).

The effects of $\mathrm{NF \kappa B}$ gene silencing on p73 were similar to those on p53. Specifically, NFkB gene silencing decreased the mRNA levels of p73 and these results showed a statistically significant difference between the scrambled control and NFKB gene-silenced groups on day 4 (Fig. 5). In addition, $\mathrm{NF} \kappa \mathrm{B}$ gene silencing inhibited the effect of $\mathrm{NF} \kappa \mathrm{B}$ induction on the mRNA levels of p73 (Figs. 4 and 5).

Notably, silencing the NFKB gene decreased the mRNA levels of AKT1, which is known to be a survival gene, at day 4 . In addition, it inhibited the effect of TNFa induction on the mRNA levels of AKT1 (Figs. 4 and 5).

Comparison of the MDM2 mRNA levels between the scrambled control and $\mathrm{NF \kappa B}$ gene-silenced groups showed that silencing the $\mathrm{NF}_{\mathrm{B}} \mathrm{B}$ gene increased the mRNA levels of MDM2 at both transfection times (Figs. 4 and 5). Silencing the $\mathrm{NF} \kappa \mathrm{B}$ gene inhibited the effect of TNF $\alpha$ on the mRNA levels of MDM2 on days 1 and 4 (Figs. 4 and 5).

The effects of $\mathrm{NF \kappa B}$ gene silencing in the presence or absence of $\mathrm{NF \kappa B}$ induction on caspase 7 and 9 were also investigated. Silencing the $\mathrm{NF} \kappa \mathrm{B}$ gene tended to decrease the mRNA levels of caspase 7 and 9, although the reductions were not statistically significant (Figs. 4 and 5). NFкB silencing decreased the mRNA levels of caspase 7 and 9 in the TNFo-induced cells (Figs. 4 and 5).

$\mathrm{NF \kappa B}$ gene silencing increased the mRNA levels of STAMP1 at day 4, and reversed the inhibitory effect of TNF $\alpha$ induction on the mRNA levels of STAMP1 at day 4 (Fig. 5).

Neither silencing the NFאB gene nor TNF $\alpha$ induction had any effect on the mRNA levels of STAMP2 (Figs. 4 and 5).

\section{Discussion}

Since, inflammation and cancer are closely related disorders (9), $\mathrm{NF} \kappa \mathrm{B}$ is a topic of particular interest to researchers (10). The activation of $\mathrm{NF} \kappa \mathrm{B}$ is generally achieved by chronic exposure 


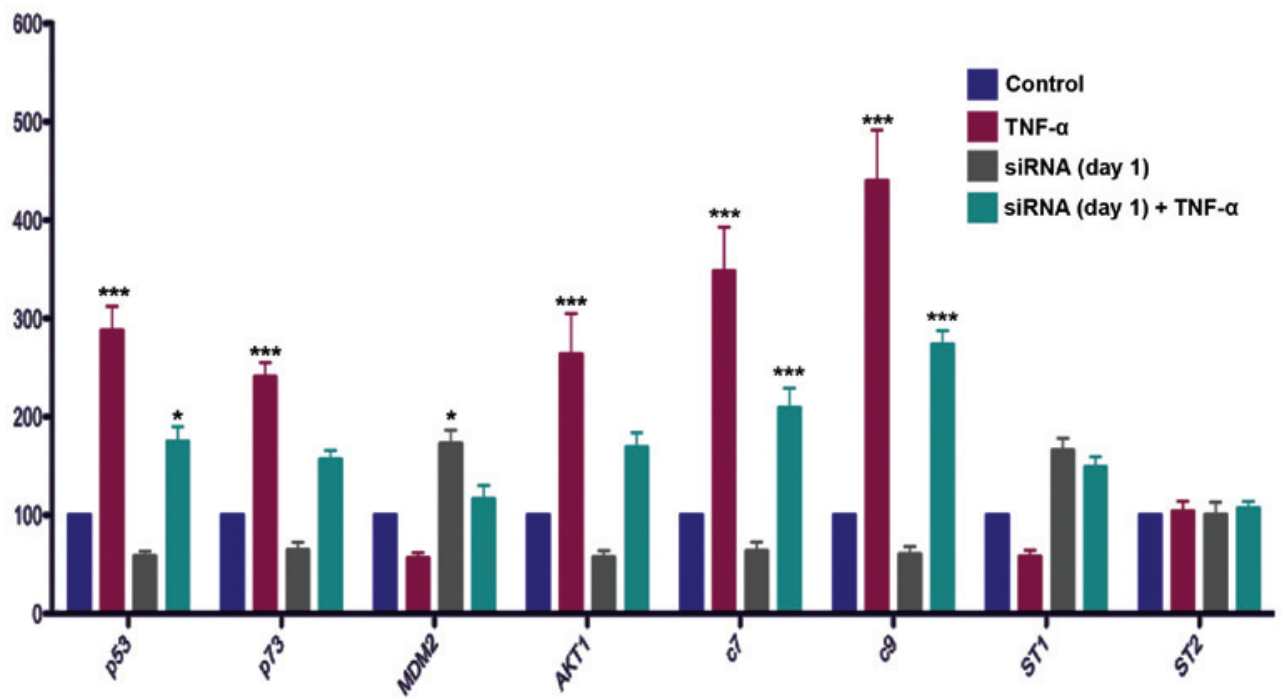

Figure 4. Effect of NFKB gene silencing (day 1) with or without TNF $\alpha$ induction on the expression of apoptosis-related genes in LNCaP cells: Cells were transfected with siNFKB construct or scrambled control for 1 day. Transfected cells were induced by TNF $\alpha$ or were not induced for a further $24 \mathrm{~h}$ in serum medium. ${ }^{*} \mathrm{P} \leq 0.05,{ }^{* * *} \mathrm{P} \leq 0.001$ vs. control, compared by one-way analysis of variance followed by Tukey post hoc test.

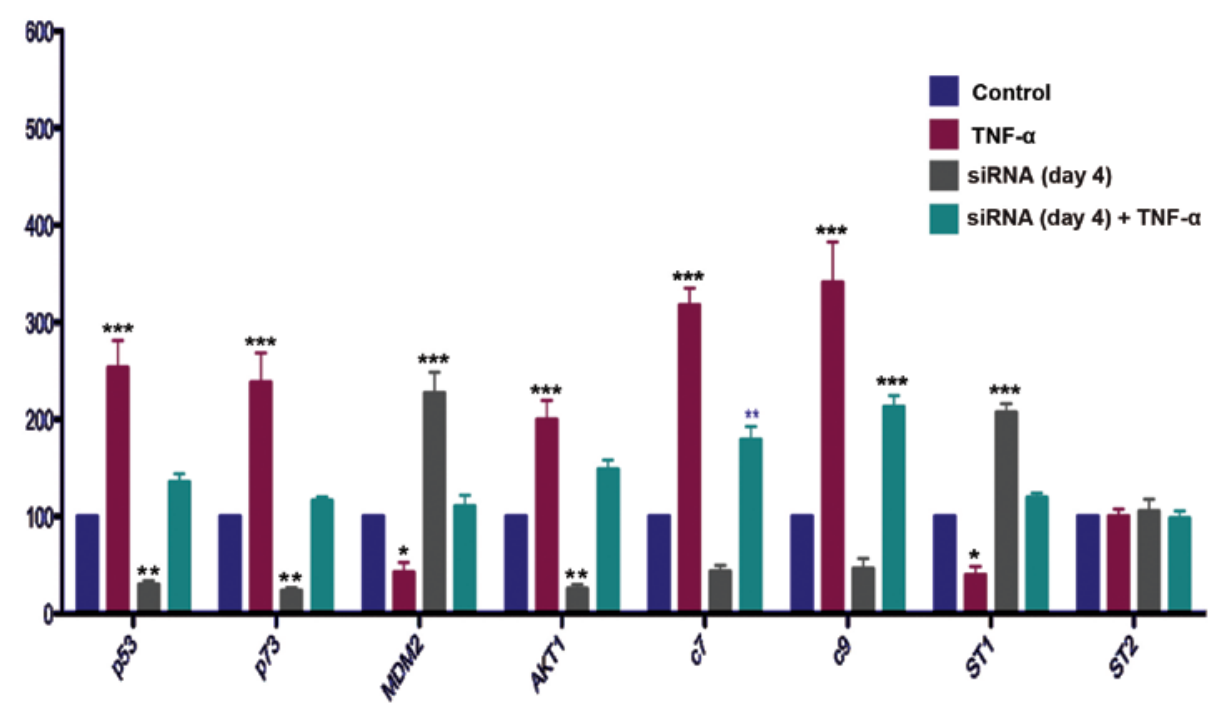

Figure 5. Effect of NFKB gene silencing (day 4) with or without TNF $\alpha$ induction on the expression of apoptosis-related genes in LNCaP cells: Cells were transfected with siNF $\mathrm{B}$ construct or scrambled control for 4 days. Transfected cells were induced by TNF $\alpha$ or were not induced on day 3 . ${ }^{*} \mathrm{P} \leq 0.05,{ }^{* *} \mathrm{P} \leq 0.01$, ${ }^{* * *} \mathrm{P} \leq 0.001$, compared by one-way analysis of variance followed by Tukey post hoc test.

to $\mathrm{TNF} \alpha$ (11). The activation results in the altered expression of various genes (12), and also the constant expression of TNF receptors R1 and R2 (data not shown). Altered gene expression has been reported in the following cell lines: DU145, which has constitutive $\mathrm{NF} \kappa \mathrm{B}$ expression, and LNCaP, which has

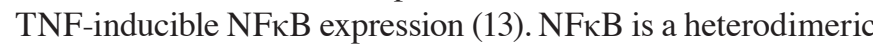
or homodimeric complex formed from five different subunits that are known as: RelA (p65), Rel B, c-Rel, NFkB1 (p50) and NFкB2 (p52). p50 and p52 subunits are derivatives of large precursor units p105 and p100, respectively. The classical $\mathrm{NF} \kappa \mathrm{B}$ heterodimer consists of p65 and p50 (14). In the present study we focused on p105 and one of its subunit, p50 (NFKB1). TNF $\alpha$ induction decreased p105 and p50 expression. This result is consistent with previous studies. The LNCaP cell line has androgen receptor expression and is therefore responsive to
R1881, an androgen analog. R1881 treatment decreased p105 expression, whereas it increased p50 expression. The DU145 cell line does not have an androgen receptor and ST1 transfection decreased p50 expression. However, TNF $\alpha$ diminished the effect of STAMP1 transfection and STAMP2 transfection increased p50 expression. Furthermore, TNFa induction has no additional effect on p50 in ST2 transfected cells. These results may indicate that further studies may reveal the correlation between androgen stimulation and the survival gene NFKB in prostate cancer. Additionally, STAMP1 and STAMP2 genes may have different and opposite roles on NFKB signaling.

In order to investigate the potential interactions, RT-qPCR amplifications using a panel of primers specific for intrinsic apoptosis were conducted in the present study. Following induction with TNFa, the mRNA levels of $\mathrm{p} 53$, which is a 
tumor suppressor (15), and p73, which is both a suppressor and supporter of cell growth (16), were found to increase. TNF $\alpha$ induction also increased mRNA levels of AKT1, a survival gene. Expression level changes of AKT1 have been previously revealed in prostate cancer cell lines (17). By contrast, the mRNA levels of MDM2, a ubiquitin ligase for p53 (18) and of STAMP1, identified as a p53 negative regulator (unpublished data), were reduced. Caspases 7 and 9 each have distinct roles during intrinsic apoptosis $(19,20)$, and it was observed in the present study that the mRNA levels of caspase 7 and 9 were increased by treatment with TNF $\alpha$. Silencing of NFKB almost completely inhibited the effects of TNF $\alpha$ induction on the expression of apoptosis related genes. This result implied that NFKB may play an important role on the regulation of apoptosis-related genes in prostate cancer. The activation of NFKB may cause chemoresistance in chemotherapy regimens (21); therefore, alternative reagents for inhibiting NFKB have been investigated $(22,23)$. Besides, the mRNA expression of STAMP1 was also decreased by TNF $\alpha$ induction. To the best of our knowledge, the present study is the first to reveal effect of TNFa induction on STAMP1. Interestingly, NFKB gene silencing increased STAMP1 expression. Regulation of STAMP1 gene expression may be related to the NFKB pathway. Conversely, STAMP2 amplification was not changed by either TNF $\alpha$ induction or NFKB silencing.

The androgen receptor (AR) is a member of the steroid receptor superfamily and a transcription factor. The response elements of prostate specific antigen (PSA) and $\mathrm{NF \kappa B}$ are located at the AR promoter region (24), and suggest that $N F \kappa B$ may effect AR expression. The activation of AKT and NFKB is reported to be involved in the progression of prostate cancer from androgen dependence to independence $(25,26)$. These findings, in combination with previous observations (27) indicate that the effective inhibition of NFKB may be critical in providing a targeted pathway for the prevention of prostate cancer.

\section{Acknowledgements}

This study was supported by grants from The Scientific and Technological Research Council of Turkey (TUBITAK) to CGK (Grant no: 106S295) and The Turkish Academy of Sciences (TUBA) to CGK (GEBIP-2007).

\section{References}

1. Lorenzo PI, Arnoldussen YJ and Saatcioglu F. Molecular mechanisms of apoptosis in prostate cancer. Crit Rev Oncog 13: 1-38, 2007.

2. Hubert RS, Vivanco I, Chen E, Rastegar S, Leong K, Mitchell SC, Madraswala R, et al: STEAP: a prostate-specific cell-surface antigen highly expressed in human prostate tumors. Proc Natl Acad Sci USA 96: 14523-14528, 1999.

3. Korkmaz KS, Elbi C, Korkmaz CG, Loda M, Hager GL and Saatcioglu F: Molecular cloning and characterization of STAMP1, a highly prostate-specific six transmembrane protein that is overexpressed in prostate cancer. J Biol Chem 277 36689-36696, 2002.

4. Korkmaz CG, Korkmaz KS, Kurys P, Elbi C, Wang L, Klokk TI, Hammarstrom $\mathrm{C}$, et al: Molecular cloning and characterization of STAMP2, an androgen-regulated six transmembrane protein that is overexpressed in prostate cancer. Oncogene 24: 4934-4945, 2005.

5. Wellen KE, Fucho R, Gregor MF, Furuhashi M, Morgan C, Lindstad T, Vaillancourt E, et al: Coordinated regulation of nutrient and inflammatory responses by STAMP2 is essential for metabolic homeostasis. Cell 129: 537-548, 2007.
6. Steiner MS, Zhang X, Wang Y and Lu Y: Growth inhibition of prostate cancer by an adenovirus expressing a novel tumor suppressor gene, pHyde. Cancer Res 60: 4419-4425, 2000.

7. Passer BJ, Nancy-Portebois V, Amzallag N, Prieur S, Cans C, Roborel de Climens A, et al: The p53-inducible TSAP6 gene product regulates apoptosis and the cell cycle and interacts with Nix and the Mytl kinase. Proc Natl Acad Sci USA 100: 2284-2289, 2003.

8. Wang L, Jin Y, Arnoldussen YJ, Jonson I, Qu S, Maelandsmo GM, Kristian A, et al: STAMP1 is both a proliferative and an antiapoptotic factor in prostate cancer. Cancer Res 70: 5818-5828, 2010.

9. Hussain SP and Harris CC: Inflammation and cancer: an ancient link with novel potentials. Int J Cancer 121: 2373-2380, 2007.

10. Morgan MJ and Liu Z: Crosstalk of reactive oxygen species and NF-кB signaling Cell Res 21: 103-115, 2011.

11. Morgan MJ, Kim YS and Liu ZG: TNFalpha and reactive oxygen species in necrotic cell death. Cell Res 18: 343-349, 2008.

12. Jablonska E, Piotrowski L and Grabowska Z: Serum levels of IL-1 $\beta$, IL-6, TNF- $\alpha$, sTNFR1 and CRP in patients with oral cavity cancer. Pathol Oncol Res 3: 126-129, 1997.

13. Mukhopadhyay A, Bueso-Ramos C, Chatterjee D, Pantazis P and Aggarwal BB: Curcumin downregulates cell survival mechanisms in human prostate cancer cell lines. Oncogene 20: 7597-7609, 2001.

14. Chen X, Kandasamy K, and Srivastava RK: Differential roles of RelA (p65) and c-Rel subunits of nuclear factor kappa B in tumor necrosis factor-related apoptosis-inducing ligand signaling. Cancer Res 63, 1059-1066, 2003.

15. Galluzzi L, Morselli E, Kepp O, Tajeddine N and Kroemer G: Targeting p53 to mitochondria for cancer therapy. Cell Cycle 7: 1949-1955, 2008.

16. Vikhanskaya F, Toh WH, Dulloo I, Wu Q, Boominathan L, $\mathrm{Ng} \mathrm{HH}$, Vousden KH and Sabapathy K: p73 supports cellular growth through c-Jun-dependent AP-1 transactivation. Nat Cell Biol 9: 698-705, 2007.

17. Deeb D, Jiang H, Gao X, Al-Holou S, Danyluk AL,Dulchavsky SA and Gautam SC: Curcumin [1,7-bis(4-hydroxy-3-methoxyphenyl)1,6-heptadiene-3,5-dione; $\mathrm{C}_{21} \mathrm{H}_{20} \mathrm{O}_{6}$ ] sensitizes human prostate cancer cells to tumor necrosis factor-related apoptosis-inducing ligand/Apo2L-induced apoptosis by suppressing nuclear factor-kappaB via inhibition of the prosurvival Akt signaling pathway. J Pharmacol Exp Ther 321: 616-625, 2007.

18. Wadgaonkar R and Collins T: Murine double minute (MDM2) blocks p53-coactivator interaction, a new mechanism for inhibition of p53-dependent gene expression. J Biol Chem 274: 13760-13767, 1999.

19. Lamkanfi M and Kanneganti TD: Caspase-7: a protease involved in apoptosis and inflammation. Int J Biochem Cell Biol 42: 21-24, 2010.

20. Brentnall M, Rodriguez-Menocal L, Ladron De Guevara R, Cepero E and Boise LH: Caspase-9, caspase-3 and caspase-7 have distinct roles during intrinsic apoptosis. BMC Cell Biol 14: 32, 2013.

21. Bharti AC and Aggarwal BB: Nuclear factor-kappa B and cancer: its role in prevention and therapy. Biochem Pharmacol 64: $883-888,2002$.

22. Bharti AC and Aggarwal BB: Chemopreventive agents induce suppression of nuclear factor-kappaB leading to chemosensitization. Ann NY Acad Sci 973: 392-395, 2002.

23. Casanelles E, Gozzelino R, Marqués-Fernández F, Iglesias-Guimarais V, Garcia-Belinchón M, Sánchez-Osuna M,

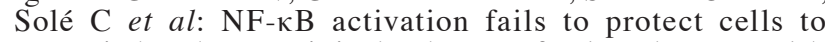
TNF $\alpha$-induced apoptosis in the absence of Bcl-xL, but not Mcl-1, Bcl-2 or Bcl-w. Biochim Biophys Acta 1833: 1085-1095, 2013.

24. Zhang L, Charron M, Wright WW, Chatterjee B, Song CS, Roy AK and Brown TR: Nuclear factor-kappaB activates transcription of the androgen receptor gene in Sertoli cells isolated from testes of adult rats. Endocrinology 145: 781-789, 2004.

25. Murillo H, Huang H, Schmidt LJ, Smith DI and Tindall DJ: Role of PI3K signaling in survival and progression of LNCaP prostate cancer cells to the androgen refractory state. Endocrinology 142: 4795-4805, 2001.

26. Kikuchi E, Horiguchi Y, Nakashima J, Kuroda K, Oya M, Ohigashi T, Takahashi N, et al: Suppression of hormone-refractory prostate cancer by a novel nuclear factor kappaB inhibitor in nude mice. Cancer Res 63,107-110, 2003.

27. Sun HZ, Yang TW, Zang WJ, Wu SF: Dehydroepiandrosteroneinduced proliferation of prostatic epithelial cell is mediated by NFKB via PI3K/AKT signaling pathway. J Endocrinol 204: 311-318, 2010. 